\title{
MANAJEMEN MUTU TERPADU \\ PADA PROGRAM STUDI MANAJEMEN PENDIDIKAN S2 PASCASARJANA UNIVERSITAS NEGERI JAKARTA
}

\begin{abstract}
Mukhneri* $^{*}$
Abstract: At present more directional orientation of the organization to fulfill the needs of customers, both existing customers within and outside the organization. So also with the quality of higher education orientation, which is directed at the needs of the community college (faculty, students, staff) as well as general community needs. The purpose of this study was to describe the implementation process of teaching and learning in higher education, service to students and the system of supervision of learning activities. While the methods used in this research is descriptive method with population research masters student educational management force from 2009 to 2010. The results of the research are as follows : 1) Implementation of the learning process in educational management department have been met, 2) Information on educational management department have also been fulfilled, 3) Service learning resources on educational management department are not entirely satisfied, including the availability of laboratory educational management, 4) Monitoring learning educational management department have been run well.
\end{abstract}

Keyword: Quality learning, customer needs and quality assurance.

\section{PENDAHULUAN}

Pada saat ini pendidikan tinggi menjadi salah satu kebutuhan masyarakat dalam rangka mendapatkan kehidupan yang lebih baik di masa yang akan datang. Oleh sebab itu perguruan tinggi harus dapat meningkatkan kualitas dalam segala bidang, agar dapat bersaing dengan perguruan tinggi lain untuk mendapatkan perhatian masyarakat. Perguruan tinggi yang tidak berkualitas, akan selalu tertinggal dan bahkan terancam untuk ditutup. Perguruan tinggi yang berkualitas diasumsikan sebagai lembaga yang dapat memenuhi harapan pelanggan atau masyarakat, baik masyarakat di luar perguruan tinggi maupun masyarakat perguruan tinggi itu sendiri, seperti dosen, mahasiswa, pegawai tata usaha dan unsur-unsur lainnnya dalam lingkup civitas akademika masing-masing perguruan tinggi.

Untuk mencapai perguruan tinggi yang berkualitas, diperlukan kemampuan manajerial dari pimpinan universitas, fakultas, jurusan dan dosen sebagai ujung tombak dalam pelaksanaan kegiatan perkulihan, baik bagi perguruan tinggi negeri maupun perguruan tinggi swasta. Setiap perguruan tinggi mempunyai kemampuan manajerial yang berbeda sesuai dengan visi dan misi dari perguruan tinggi masing-masing. Kemampuan manajerial dari masing-masing pimpinan perguruan tinggi hendaklah selalu diarahkan pada harapan pelanggan yang dimulai dari kegiatan perencanaan, pengorganisasian, pengkoordinasian, penganggaran maupun pengawasan dari sumberdaya yang ada pada masing-masing perguruan tinggi sesuai dengan kebutuhan dan harapan pelanggan.

Kebutuhan dan harapan pelanggan tersebut, seringkali belum terpenuhi secara maksimal oleh masing-masing perguruan tinggi, baik untuk masyarakat umum maupun untuk masyarakat perguruan tinggi itu sendiri. Harapan bagi masyarakat

\footnotetext{
* Dosen Program Pascasarjana Universitas Negeri Jakarta (Gd. M Kampus UNJ Jl. Rawamangun Muka, Jakarta Timur)
} 
umum, hasil pendidikan di perguruan tinggi dapat mereka pergunakan untuk melangsungkan kehidupan mereka di tengah-tengah masyarakat, mereka berharap dengan modal pendidikan tinggi, mereka akan memenuhi kebutuhan masyarakat dan mendapat kehidupan yang layak atas investasi yang telah mereka tanamkan selama ini. Bagi masyarakat perguruan tinggi seperti tata usaha, dosen, mahasiswa dan civitas akademika lainnya membutuhkan layanan yang berkualitas, yaitu layanan yang sesuai dengan harapan civitas akademika.

Segala kegiatan untuk pencapaian kualitas yang diharapkan civitas akademika perguruan tinggi, hendaklah selalu dimonitoring, dikendalikan, dan dievaluasi melalui kegiatan pengawasan yang terencana, terorganisir dan sistematis untuk mencapai efektivitas dan efesiensi pelaksanaan kegiatan di perguruan tinggi. Bagi dosen, permasalahan yang sering dihadapi adalah tidak sesuainya antara harapan dengan kenyataan yang dihadapi masing-masing staf pengajar dalam memberikan pelayanan yang diinginkan ataupun yang diharapkan oleh mahasiswa, sehingga proses belajar mengajar berlangsung apa adanya dan tentunya kondisi ini akan mempengaruhi kualitas atau mutu yang menjadi harapan masyarakat. Bagi perguruan tinggi negeri, terutama Program Studi Magister Manajemen Pendidikan (S2) pada Program Pascasarjana Universitas Negeri Jakarta isu-isu yang telah dibicarakan sebelumnya sudah dirasakan dosen maupun mahasiswa, karena setiap hari mereka membandingkan antara konsep-konsep dan kegiatan manajemen dengan kegiatan nyata di lapangan, sehingga kondisi yang demikian perlu diteliti.

Adapun rumusan masalah dalam penelitian ini adalah: (1) Bagaimanakah pelaksanaan proses belajar mengajar yang dilakukan dosen pada program studi manajemen pendidikan (S2)?, (2) Bagaimanakah pelayanan informasi yang diberikan program studi manajemen pendidikan S2 terhadap penyelesaian tesis mahasiswa?, (3) Bagaimanakah pelayanan sumber belajar yang diberikan kepada mahasiswa program studi manajemen pendidikan (S2), dan (4) Bagaimanah proses pengawasan yang dilakukan program studi manajemen pendidikan (S2) terhadap kegiatan mahasiswa?

\section{Mutu Pendidikan}

Dalam kegiatan pembelajaran di perguruan tinggi selalu memperhatikan konsep mutu, yaitu bagaimana perguruan tinggi memberikan pelayanan terbaik kepada mahasiswa, dosen, staf tatausaha dalam rangka memenuhi kebutuhan mereka sehingga akan tercapai kepuasan dan sekaligus memenuhi harapan masyarakat perguruan tinggi maupun masyarakat umum.

Konsep mutu yang telah dicanangkan di perguruan tinggi, lebih di kenal dengan manajemen mutu terpadu, yang menitikberatkan bagaimana memberikan pelayanan terbaik kepada para pelanggan yang ada di perguruan tinggi maupun di luar perguruan tinggi. Adapun standar mutu yang akan dilaksanakan perguruan tinggi adalah

berhubungan dengan bagaimana menyelenggarakan manajemen keuangan, manajemen kurikulum dan pembelajaran, manajemen personalia, manajemen ketatausahaan, manajemen hubungan perguruan tinggi dengan masyarakat, manajemen kemahasiswaan dan manajemen sarana dan prasarana pendidikan.

Standar mutu tersebut di atas dilakukan untuk melayani segala kebutuhan masyarakat perguruan tinggi, terutama mahasiswa sebagai pelanggan yang menjadi fokus utama dalam memberikan pelayanan yang maksimal, sehingga semua harapan mereka dapat dipenuhi oleh perguruan tinggi. 


\section{Mutu Pembelajaran di Perguruan Tinggi}

Kegiatan pembelajaran di perguruan tinggi merupakan tanggungjawab dosen dan pengelola jurusan maupun program studi, untuk melayani kebutuhan mahasiswa semaksimal mungkin. Kegiatan tersebut dimulai dari kegiatan perencanaan pembelajaran atau perkuliahan pada masing-masing mata kuliah yang sesuai dengan kebutuhan mahasiswa. Di samping itu, yang tak kalah penting adalah bagaimana merealisasikan kegiatan tersebut sesuai dengan rencana yang telah ditetapkan sebelumnya, baik yang dilakukan dosen maupun pengelola pendidikan.

\section{Pengawasan Mutu Pendidikan}

Pengawasan merupakan salah satu fungsi manajemen yang ikut mewarnai tercapainya tujuan organisasi, benda maupun manusia. Pengawasan pada dasarnya dapat diartikan sebagai kegiatan untuk mengevaluasi, mengendalian kegiatan sesuai dengan rencana organisasi yang telah ditetapkan sebelumnya. Pengawasan dilakukan untuk memastikan anggota organisasi melaksanakan apa yang dikehendaki seseuai dengan tujuan organisasi, dengan cara mengumpulkan, menganalisis dan mengevaluasi informasi dengan tujuan untuk mengendalikan kegiatan sesuai dengan tujuan yang telah ditetapkan. Sedangkan Gibson et al (1982) merumuskan pengawasan sebagai kegiatan manajerial untuk menjamin bahwa hasil dapat dicapai sesuai dengan rencana dengan cara menyelesaikan urutan pekerjaan secara logis dengan melakukan penempatan, pemeriksaan bahan, evaluasi kerja, dan teknik manajerial.

Pengawasan atau controlling terdiri dari unsur-unsur tindakan korektif, karena controlling itu sebenarnya dapat berarti pula pengendalian. Jadi dapat dikatakan pengawasan adalah standar atau tolok ukur, yang paling tidak mengandung tiga segi, yaitu sesuai dengan rencana yang sudah ditetapkan, sesuai dengan peraturan perundang-undangan dan ketentuan lain yang berlaku serta memenuhi prinsip-prinsip daya guna (efisiensi) dan hasil guna (efektifitas).

Pengawasan sebagai suatu usaha sistematik untuk menetapkan standar pelaksanaan dengan tujuan-tujuan perencanaan, merancang sistem informasi umpan balik, membandingkan kegiatan nyata dengan standar yang telah ditetapkan sebelumnya, menentukan dan mengukur penyimpangan-penyimpangan, serta mengambil tindakan koreksi yang diperlukan untuk menjamin bahwa semua sumber daya perusahaan dipergunakan dengan cara paling efektif dan efisien dalam pencapaian tujuan-tujuan organisasi.

\section{METODE}

Penelitian ini menggunakan paradigama kuantitatif dengan pendekatan deskriptif. Adapun populasi penelitian adalah dosen, sekretaris dan ketua program studi manajemen pendidikan S2 pada Program Pascasarjana Universitas Negeri Jakarta. Sedangkan yang dijadikan responden dalam penelitian ini adalah seluruh mahasiswa program studi manajemen pendidikan S2.

Analisis data menggunakan metode deskriptif, dengan formula:

$$
\mathrm{P}=\frac{\mathrm{F}}{\mathrm{N}} \times 100
$$




\section{HASIL DAN PEMBAHASAN}

Penyebaran kuesioner difokuskan untuk menjaring data terkait pelaksanaan proses belajar mengajar yang dilakukan dosen, pelayanan informasi yang diberikan program studi manajemen pendidikan S2 terhadap penyelesaian tesis mahasiswa, pelayanan sumber belajar yang diberikan kepada mahasiswa dan proses pengawasan yang dilakukan program studi manajemen pendidikan (S2) terhadap kegiatan mahasiswa. Kuesioner ini mempunyai lima alternatif jawaban, yaitu: selalu (5), sering (4), kadang-kadang (3), jarang (2), dan tidak pernah (1).

Pelaksanaan proses belajar mengajar dalam organisasi perguruan tinggi, dapat digambarkan melalui kurikulum yang fleksibel, ketersediaan silabus perkuliahan, sarana pembelajaran, bimbingan tesis dan sistem evaluasi. Pada aspek kurikulum, memuat enam pernyataan, yaitu: 1) Muatan lokal sesuai dengan kebutuhan mahasiswa, 2) Muatan cocok untuk masa kini, 3) Muatan responsif dan tanggap untuk pengembangan program baru, 4) Muatan merupakan masukan dari pelanggan, 5) Muatan merupakan masukan dari pelanggan, dan 6) Muatan dapat sebagai penghubung dengan masyarakat. Hasil dari penyebaran kuesioner diperoleh informasi bahwa 55,3\% responden menjawab sering, 17,9\% menjawab selalu, 17,6 menjawab kadang-kadang, 6,6\% menjawab jarang dan 4,5\% menjawab tidak pernah.

Pada aspek ketersediaan silabus perkuliahan, memuat lima pernyataan, yaitu: 1) Dosen menyusun silabus perkuliahan, 2) Silabus perkuliahan yang digunakan mahasiswa seragam, walaupun dosennya berbeda, 3) Dalam silabus perkuliahan memuat kompetensi-kompetensi pembelajaran sebagai standar mutu, 4) Materi yang ditawarkan dalam silabus tumpang tindih dengan mata kuliah yang berbeda, dan 5) Dosen membuat kesepakatan dengan mahasiswa tentang sistem perkuliahan yang akan dilaksanakan. Hasil dari penyebaran kuesioner diperoleh informasi bahwa 39,16\% responden menjawab sering, 28,98\% menjawab jarang, 13,68\% menjawab kadangkadang, 17\% menjawab selalu dan 1,18\% menjawab tidak pernah.

Pada aspek sarana pembelajaran, memuat lima pernyataan, yaitu: 1) Strategi pembelajaran yang digunakan dosen sesuai dengan harapan mahasiswa, 2) Dosen menggunakan beberapa pedoman untuk meningkatkan cara belajar mahasiswa, 3) Dosen memiliki kompetensi menggunakan berbagai strategi perkuliahan, 4) Penggunaan sistem pembelajaran yang berpusat pada mahasiswa, 5) Menggunakan alat audio visual yang relevan dengan kebutuhan perkuliahan. Hasil dari penyebaran kuesioner diperoleh

informasi bahwa 38,18\% responden menjawab sering, 21,7\% menjawab selalu, 17,4\% menjawab tidak pernah, 12,98\% menjawab kadang-kadang dan 9,74\% menjawab jarang.

Pada aspek proses bimbingan terhadap mahasiswa, memuat lima pernyataan, yaitu: 1) Dosen melayani mahasiswa sesuai dengan harapan dan kebutuhan mahasiswa, 2) Dosen memberikan bimbingan untuk kelancaran studi mahasiswa, 3) Dosen membeda-bedakan dalam pemberian layanan kepada mahasiswa, 4) Dosen memberikan semangat dan motivasi kepada mahasiswa untuk cepat menyelesaikan perkuliahan, 5) Dosen pembimbing mempunyai kompetensi sesuai dengan bidang ilmu yang menjadi kajian mahasiswa. Hasil dari penyebaran kuesioner diperoleh informasi bahwa 34,62 \% responden menjawab sering, 28,88\% menjawab selalu, 22,76\% menjawab tidak pernah, 10,12\% menjawab kadang-kadang dan 3,62\% menjawab jarang.

Pada aspek evaluasi pembelajaran, memuat lima pernyataan, yaitu: 1) Dosen terbuka dalam memberikan nilai kepada mahasiswa, 2) Dosen objektif dalam menilai tugas, kuis, ujian tengah semester dan akhir semester, 3 Hasil penilain yang diberikan 
dosen sesuai dengan target masing-masing mahasiswa, 4) Dosen memberikan penilaian sesuai dengan kemampuan mahasiswa, dan 5) Dosen memberikan kesempatan kepada mahasiswa untuk memperbaiki nilai yang tidak sesuai dengan harapan mahasiswa. Hasil dari penyebaran kuesioner diperoleh informasi bahwa 34,62\% responden menjawab sering, 23,52\% menjawab selalu, 17,6\% menjawab kdang-kadang, 13,74\% menjawab tidak pernah dan 10,52\% menjawab jarang.

Selanjutnya mengenai rangkuman jawaban responden terkait pelaksanaan proses belajar mengajar dapat dilihat pada gambar berikut ini:

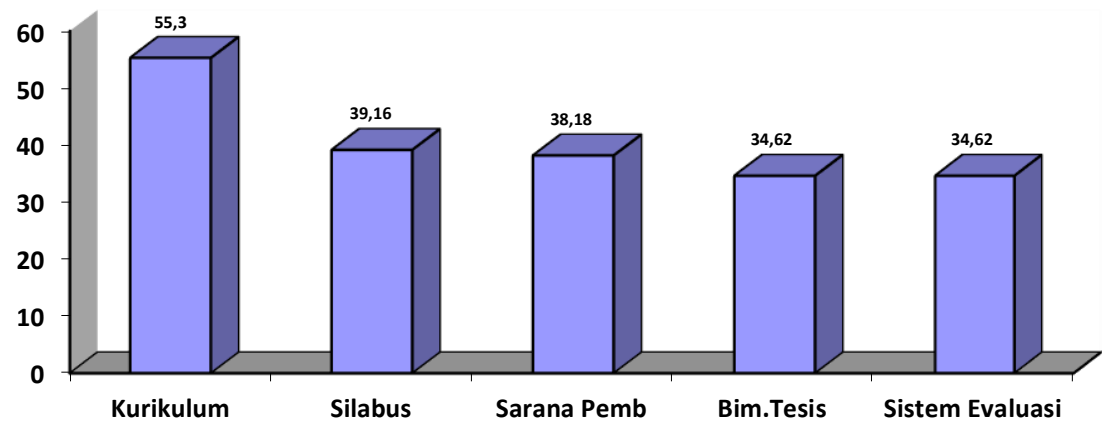

Gambar 1.

Rangkuman jawaban responden terkait pelaksanaan proses belajar mengajar

Pelayanan informasi pada program studi manajemen pendidikan ditunjukkan dengan indikator: ketersediaan buku pedoman dan ketersediaan informasi yang menunjang pelaksanaan kegiatan pembelajaran di perguruan tinggi. Pada aspek ketersediaan buku pedoman, memuat lima pernyataan, yaitu: 1) Program perguruan tinggi, 2) Keahlian yang dicapai mahasiswa, 3) Waktu yang dicapai untuk keahlian dan keterampilan, 4) Prasyarat administrasi, dan 5) Visi dan misi serta peraturan perguruan tinggi. Hasil dari penyebaran kuesioner diperoleh informasi bahwa 34,78\% responden

menjawab sering, 25,8\% menjawab tidak pernah, 20,74\%menjawab selalu, 10,66\% menjawab kadang-kadang dan 8,02\% menjawab jarang.

Pada aspek ketersediaan informasi umum, memuat lima pernyataan, yaitu: 1) Rambu-rambu petunjuk lokasi, 2) Jadwal perkuliahan, 3) Jadwal bimbingan bagi mahasiswa, 4) Sistem pelayanan yang diberikan program studi, dan 5) Kejelasan informasi dari unit-unit yang terkait dalam melayani mahasiswa. Hasil dari penyebaran kuesioner diperoleh informasi bahwa 33,52\% responden menjawab selalu, 31,36\% menjawab sering, 21,38\% menjawab tidak pernah, 8,78\% menjawab kadang-kadang dan $4,96 \%$ menjawab jarang.

Pada aspek ketersediaan Informasi tentang Karir dan Kesempatan Kerja, memuat lima pernyataan, yaitu: 1) Kesempatan kerja bagi mahasiswa yang belum bekerja, 2) Bimbingan karir bagi mahasiswa yang sudah bekerja, 3) Kegiatan seminar dan lokakarya untuk meningkatkan wawasan mahasiswa, 4) Menyelenggarakan kegiatan magang mahasiswa dengan dunia kerja, dan 5) Kerjasama antara mahasiswa dalam kegiatan ilmiah perguruan tinggi. Hasil dari penyebaran kuesioner diperoleh informasi bahwa 31,18\% responden menjawab sering, 23,62\% menjawab tidak pernah, $18,96 \%$ menjawab kadang-kadang, 13,76\% menjawab selalu dan 12,48\% menjawab jarang. 
Selanjutnya mengenai rangkuman jawaban responden terkait pelayanan informasi dapat dilihat pada gambar berikut ni:

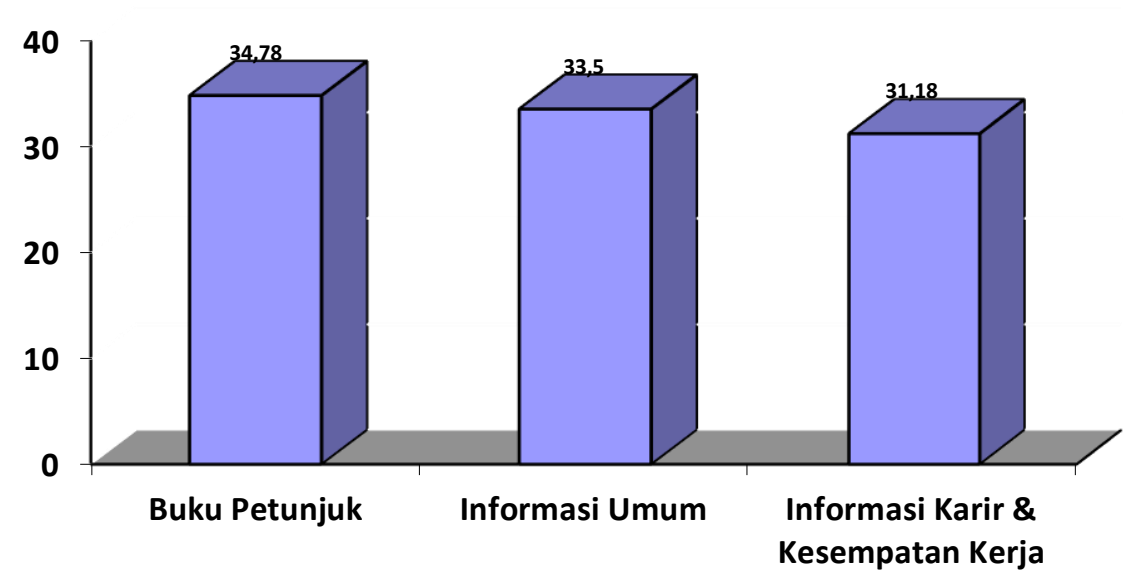

Gambar 2.

Rangkuman jawaban responden terkait pelayanan informasi

Pelayanan sumber belajar pada program studi manajemen pendidikan S2 pada Pascasarjana UNJ dapat dilihat dari: sarana fisik, perpustakaan, dan laboratorium. Pada aspek sarana fisik, memuat lima pernyataan, yaitu: 1) Ruang dosen untuk konsultasi mahasiswa, 2) Ruang perkuliahan yang layak, 3) Ruang auditorium yang digunakan untuk kegiatan yang beragam, 4) Ruang program studi yang representatif, dan 5) Ruangan audio visual yang lengkap. Hasil dari penyebaran kuesioner diperoleh informasi bahwa 33,8\% responden menjawab selalu, 31,48\% menjawab sering, 12,9\% menjawab tidak pernah, 12,7\% menjawab kadnag-kadang dan 9,12\% menjawab jarang.

Pada aspek perpustakaan perguruan tinggi, memuat enam pernyataan, yaitu: 1) Tersedianya buku-buku teks, jurnal, reverensi dan buku literature lainnya, 2) Sistem perpustakaan tertata baik, 3) Ruang baca yang cukup dan memadai, 4) Ruang baca tertib, nyaman dan bersih, 5) Tersedianya media cetak dan elektronik, dan 6) Tersedianya jam buka perpustakaan 10 jam perhari. Hasil dari penyebaran kuesioner diperoleh informasi bahwa 30,27\% responden menjawab sering, 28,7\% menjawab selalu, $22,94 \%$ menjawab tidak pernah, 12,02\% menjawab kadang-kadang dan 6,07\% menjawab jarang.

Pada aspek laboratoritum pascasarjana, memuat lima pernyataan, yaitu: 1) Laboratorium bahasa, 2) Laboratorium komputer, 3) Laboratorium manajemen, 4) Kelompok studi peneliti muda, dan 5) Lembaga pendukung untuk kegiatan ilmiah. Hasil dari penyebaran kuesioner diperoleh informasi bahwa $38,14 \%$ responden menjawab tidak pernah, 20,86\% menjawab kadang-kadang, 17,58\% menjawab sering, $12,28 \%$ menjawab jarang dan $11,14 \%$ menjawab selalu.

Selanjutnya mengenai rangkuman jawaban responden terkait pelayanan sumber belajar dapat dilihat pada gambar berikut ni: 


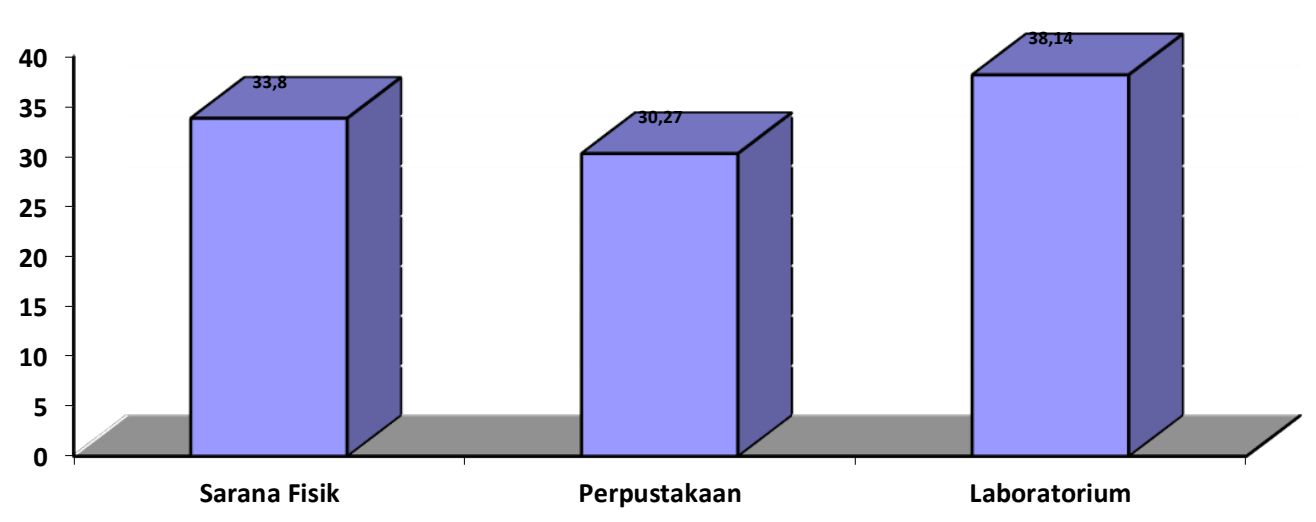

Gambar 3.

Jawaban responden terkait pelayanan sumber belajar

Pengawasan pembelajaran program studi manajemen pendidikan S2 Pascasarnana UNJ memuat dua pernyataan, yaitu: 1) Pengawasan program studi, dan 2) Pengawasan direktur. Hasil dari penyebaran kuesioner diperoleh informasi bahwa $41,2 \%$ responden menjawab sering, 22,65\% menjawab selalu, $19,65 \%$ menjawab kadangkadang, $12,65 \%$ menjawab jarang dan 3,85\% menjawab tidak pernah. selanjutnya dapat dirangkum pada gambar berikut:

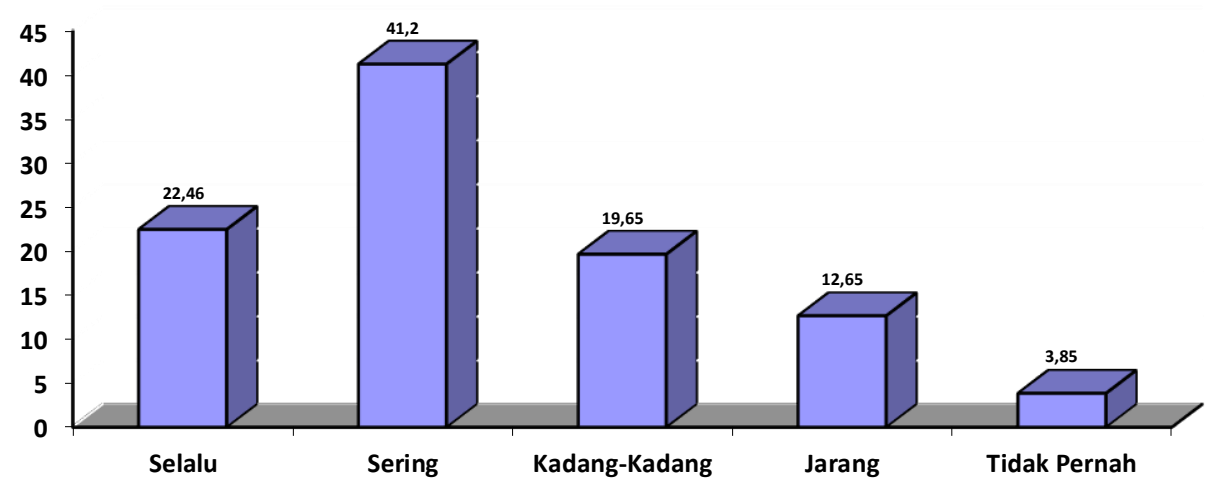

Gambar 4

Pengawasan Pembelajaran

\section{PENUTUP}

Kesimpulan. Berdasarkan pembahasan di atas, maka dapat disimpulkan bahwa: Pertama, pelaksanaan proses belajar mengajar di program studi manajemen pendidikan yang digambarkan melalui kurikulum yang fleksibel, ketersediaan silabus perkuliahan, sarana pembelajaran, bimbingan tesis dan sistem evaluasi telah terpenuhi. Kedua, Pelayanan informasi pada program studi manajemen pendidikan ditunjukkan dengan ketersediaan buku pedoman dan ketersediaan informasi yang menunjang pelaksanaan 
kegiatan pembelajaran di perguruan tinggi telah terpenuhi. Ketiga, Pelayanan sumber belajar pada program studi manajemen pendidikan yang dilihat dari: sarana fisik, perpustakaan, dan laboratorium tidak seluruhnya terpenuhi, diantaranya ketersediaan laboratorium manajemen pendidikan. Keempat, Pengawasan pembelajaran program studi manajemen pendidikan yang meliputi pengawasan program studi, dan pengawasan direktur menunjukkan bahwa pengawasan telah berjalan dengan baik.

Saran. Beberapa saran yang dapat diusulkan dalam rangka perbaikan manajemen mutu di program studi manajemen pendidikan antara lain:1) Para dosen diharapkan dapat lebih meningkatkan kualitas pembelajaran di kelas melalui pemberian silabus kepada mahasiswa sebagai pedoman selama perkuliahan dan juga dalam pemberian nilai diharapkan lebih objektif yang dilihat dari berbagai aspek. Selain itu juga dosen diharapkan dapat lebih mudah ditemui secara langsung untuk dapat memberikan bimbingan tesis pada mahasiswa dan juga memberitahukan informasi bimbingan secara jelas. 2) Pihak Program studi diharapkan dapat menyediakan buku petunjuk penyelesaian studi pada tiap mahasiswa yang dapat dijadikan pedoman dan juga menyediakan informasi mengenai karir dan kesempatan kerja bagi lulusan program studi manajemen pendidikan. 


\section{DAFTAR RUJUKAN}

Gibson, J.L., Ivancevich, J.M., Donnely, J.H. (1982). Organizations. Terjemahan Djoerban Wahid. Jakarta: Erlangga

Hamton, D. (1987). Management. Third Edition, Singapore: McGraw-Hill Book Company.

Koontz, H., Cyril., Heinz, W. (1980). Management. Eighth Edition. London.

Donnelly, J. James, H., James L., \& John, I. (1984). Fundamental Management. United States of America. Business Publication, Inc.

Terry, George. (1977). Principles Management. Illinois: Richard D. Irwin. Inc.

Stoner, James. (1986). Management. Third Edition. New Jersey. Prentice-Hall.

David L. Goetsch and Stanley B. Davis (2000), Quality Management. New Jersey: Prentice Hall, Inc

Ralph G. Lewis., Douglas H. Smith (1994). Total Quality in Higher Education. Florida: St. Lucie Press. 